\title{
Social media among homosexuals: A new era of gay life in the age of technology
}

\author{
Sosial media di kalangan kaum gay: Era baru kehidupan gay di era \\ perkembangan teknologi
}

\author{
Mustangin \\ Department of Nonformal Education, Universitas Mulawarman \\ Address: Jalan Kuaro, Samarinda, East Kalimantan 75119 \\ E-mail: mustangin1992@gmail.com
}

\begin{abstract}
The gay community in Indonesia is still considered to be a minority and not widely accepted by the general public. Therefore, many of gay individuals are looking for an alternative to be able to meet others through a community. Furthermore, the development of the media nowadays has contributed to the emergence of numerous social media created specifically for homosexuals to meet each one another. This study aims to reveal the phenomenon of social media specifically created for gay men, including the nature of the activities carried out and its purpose for the gay community. This study is a qualitative research study, conducted using a case study. This study found that social media specifically created for gay men is used as a tool to make friends, to communicate, and to be socially accepted. Their activity on social media is initiated with an introduction, similar to other social media. However, this social media possesses a gay radar that enables the user to find fellow gay men in their surroundings. The emergence of this gay-specific social media is a phenomenon caused by the development of technology. This particular form of social media is utilized by the gay community to interact with one another and to let their identity as a human to be acknowledged.
\end{abstract}

Keywords: gay; social media; technological development

\begin{abstract}
Abstrak
Gay bagi masyarakat di Indonesia masih dianggap sebagai kaum minoritas yang keberadaannya belum bisa diterima oleh masyarakat, sehingga banyak dari kaum gay yang mencari alternatif untuk dapat bertemu dengan sesama gay melalui komunitas, selain itu dengan perkembangan media saat ini telah banyak bermunculan sosial media yang khusus diciptakan untuk mendukung para gay untuk bertemu dengan sesama gay. Penelitian ini bertujuan untuk mengungkap fenomena kemunculan sosial media khusus bagi kaum gay dan fungsi penggunaan sosial media tersebut bagi kaum. Penelitian ini menggunakan metode penelitian kualitatif dan jenis penelitiannya studi deskriptif dari kasus yang ditemukan. Hasil penelitian menemukan bahwa sosial media khusus kaum gay berperan sebagai media mencari teman, media komunikasi dan media untuk pemenuhan kebutuhan untuk diterima, selain itu aktivitas gay di sosial media dilakukan dengan perkenalan pada umumnya di sosial media, namun hal yang menarik bahwa sosial media khusus gay ini terdapat gay radar yang memudahkan kaum gay untuk menemukan sesama gay di daerah terdekatnya. Adanya sosial media khusus kaum gay ini adalah sebagai fenomena yang timbul dari adanya perkembangan teknologi yang semakin canggih. Kehadiran sosial media dimanfaatkan oleh kaum gay untuk dapat berinteraksi dengan sesama gay, sehingga gay merasa diakui sebagai seorang manusia yang memiliki identitas diri.
\end{abstract}

Kata kunci: gay; perkembangan teknologi; sosial media

\section{Introduction}

Homosexuality as a phenomenon in Indonesia has been a serious topic of debate, particularly since several countries have legalized same-sex marriage. The decision to legalize same-sex marriage is opposed to in Indonesia, as it is contrary to the customs and culture of society. Sujana, Setyawati, \& Ujanti (2018) stated that the existence of LGBT+ individuals, especially gay men, is still deemed to be a deviant behavior by some people; more so with their willingness to marry and build a family. This has caused the gay community to be a minority in Indonesia. The gay community has the desire to be accepted as normal members of society. Society has deemed gay men to be a minority through their deviant sexual behavior. Some people even regard the gay community as a serious threat to future generations and therefore, they are a problem that needs to be solved. The opposition to gay men triggered them to find a space for them to be accepted in their own way. It was explained by 
Frost \& Meyer (2012) that gay men have adopted various methods to abolish prejudice, including developing a community where one can support other due to sense of belonging and similarity (Chong et al. 2015), therefore numerous communities in Indonesia whose vision is to promote gay rights exist. There are many communities in Indonesia whose vision and missions is to promote and voice gay rights. Due to the issues explained previously, Harahap (2016) divided the LGBT phenomenon in Indonesia into two entities. First, is as an individual disease caused by medical (biological/genetic) and sociological factors or the environment and their surroundings. The second entity is as a community or organization which owns a movement.

Information and technology development nowadays increases accessibility, allowing society to find anything. This increasing accessibility is widely used by gay men to appeal for their existence. Wijoyo (2016) mentioned that the LGBT community has existed in Indonesia for a long time, but the recent legalization of same-sex marriage in other countries has triggered the gay community in Indonesia to demand the government's acknowledgement of their existence. Moreover, the globalization of communication enables information to flow in without any substantial obstacles. The development of information technology increases the possibility to make friends through social networking sites. Various social media nowadays can be used to make new friends. Social media is also used by gay men to find new friends. Nowadays there are certain social media networks that are specifically designed for gay men to make new friends. Therefore, this research will study homosexual activity when using social media as a tool to appeal for their existence through online social media.

Homosexuals are, in this study, men who are attracted to the same sex. Chauncey (1994) defined being gay as being sexually attracted to the same-sex (Fassin \& Salcedo 2015). This argument is supported by Santrock (2013), in that use the term of the gay refers to one whose sexual attraction is toward the same-sex. The existence of homosexuals in Indonesia has created controversy in Indonesia, as some people have deemed the tendency to be attracted to same-sex as not being in accordance with the common norms in Indonesia. These norms and inappropriateness have caused gay men to have a low level of confidence when it concerns coming out to the public or even within their nuclear family unit. According to a report by the Department of Health and Ageing Australia (2012), the reason behind gay men's preference to identify and socialize among other gay men is due to the strong connections within the gay community. This is caused by the rejection that gay individuals receive from their biological family; therefore they form a close kinship with their non-biological family, whom they refer to as family of their choice. The presence of this community can be more significant to them than their own immediate family members because, as mentioned before, this community is willing to accept them as they are.

The advancement of technology and information has resulted in innovations that have increased the accessibility of various things, including the convenience of making friends through social media. As explained by Okereke and Oghenetega (2014), life has been made easier by the available access to various things including social and political networks, which are always interconnected everywhere. Achew \& Larson (2015) stated that social media holds the role of being a platform that enables people to communicate, to share information, and to create new relationships. Gay men also use social media for multiple purposes. This convenience when using social media can be seen in its simple methods of use.

The utilization of social media by gay men is as one of the platforms that enables them to find particular people that they want to. The emergence of social media designed specifically for gay men is the answer to their anxiety over the negative prejudices held against them by society. There are multiple social media networks, especially for homosexuals, that are accessible through a computer or smartphone in Indonesia. This is in line with Puspita (2015), who explained that internetconnected communication technology such as computers and smartphones enables society to find information quickly and allows them to communicate freely. For example, the use of Facebook as a form of widely popular social media is also used by gay men to make new friends. Some social media networks specifically designed for gay men in Indonesia include Grindr, Badoo, Jack'd, Tagged, and 
Scruff. The variety of social media these days indicates the availability of diverse open space. In this research, social media is defined as a social media service that provides platforms for people to make new friends. The social media studied in this research is focused on the utilization of Jack' $D$ for gay men in their building of an online social community network.

\section{Research Method}

This research used a qualitative approach, utilizing a case study as its research method. This research used a qualitative approach to uncover LGBT activities on social media in order to show their existence through online communities. The method of a case study was used because this research has specifically examined the users of one type of social media.

The participants in this study were gay people who use social media specifically designed for gay men, named Jack'D. Jack'D users were chosen because the participants had direct experience in making friends on social media. Moreover, Jack'D is one of the social media networks that is currently the most widely used among gay men, because it is the only social media application for gays that is available through the App Store, Playstore, and Windows Phone Store. The specific location and population chosen was high school students and university students in the city of Bandung and its surroundings. This area was selected because according to the data held, West Java has the highest number of gay men in Indonesia, while the city of Bandung is one of cities in West Java and also its capital city. Furthermore, Bandung City is one of the regions with a high level of modernity. Therefore, the use of social media is an integral part of people's daily lives.

The procedure for the data collection was the most strategic step in this research. This is because the main purpose of the research itself was to obtain data. Thus, without knowing the data collection techniques, the researcher will not be able to obtain the data that meets the applied standards. The data collection techniques used in this study were as follows: interviews, participant observation, and document study.

The type of data collection conducted is very crucial to this study, and was in the form of data obtained through questions and answers to and from the informant. To gather information from this kind of data, the researchers used unstructured interviews and in-depth interviews in various situations. This is to create an intimate atmosphere between the researchers and informants. This approach was used to get data that had a certain depth and level of detail. The interviews related to social media were done through direct online chatting in order to get more accurate responses. The data collection conducted through observations was obtained by learning the features provided by Jack'D as one of the social media networks created especially for gay men. Studying the profiles of the participants on Jack'D and approaching them in order to get supporting research data has been included in the data collection.

The data collection was done by reviewing the documents related to this research. This was used as additional data to support the main data obtained from the previous data collection techniques, so then more data was available to determine the answers to the problems proposed in this research.

\section{Result and Discussion}

There are many ways that gay men obtain self-actualization, one of which is to use social media as a tool. Social media consists of a collection of individuals who gather in a wide network so then anyone can get acquainted. Social media as a social networking site, according to Mingle, Adams, \& Adjei (2016), has become an interesting part of life. One of the interesting things is that people can easily built friendships with new people who possess the same interests. Gay men can easily make friends, especially with special social media services designed for homosexuals. The discussion on the findings of the use of social media for gay men can be seen in the activities of gay men utilizing social media and the important role that social media plays. 


\section{Social media specifically designed for gay men}

Analyzing the features found on Jack' D, it was designed specifically to make it easier for gay men to get and make friends according to their preferences. Indeed, what is interesting is that there is a feature called gay radar that utilizes GPS. This makes it easier for gay men to find users that are located in close proximity to them. This also indicates that this social media platform is gay-friendly. Moreover, this social media platform has profile photo feature. As per explained by Baruah (2012) that the advantage of social media is its ability to allow users to create profiles or personal homepages online and build social networks. This personal webpage contains the user's profile information. The reason for this feature, according to Nwazor \& Godwin-Maduike (2015), is because social media consists of activities that involve socializing and networking online through words, pictures and videos. The profile photo feature eases gay men into establishing inter-gay networks on social media.

As one of the emerging social media platforms these days, Jack' $D$ is widely popular. The users of this application varied from those who had been using it for three years, for one year, and for one month. This social media platform is an innovation for gay men. Innovation, as is generally known, is a product, process and organizational change that does not necessarily originate from new scientific discoveries; it can arise from a combination of existing technology in a new context (Hana 2013). Judging from the additional features of new social media, there are additional gay radars equipped with GPS for men to be able to easily find fellow users around them.

However, in reality, the use of this new innovation varied among the users; there were those who had never used social media before and those who were still new to using social media specifically designed for gay men. This phenomenon is in line with idea of Hanafi (1981), which explains that the novelty of an innovation is subjectively based on its beholder. For some men, Jack'D is a new item, but there are those who have been using it for so long that it may not be as new to them; thus, everything depends on one's perspective. The use of Jack'D for gay men differs according to how the users obtain information about this social media platform itself. Gay men who learn about Jack'D quicker can start using the application earlier than others.

Social media applications have become a part of gay life because they have features that are beneficial. As an innovation created to meet their needs, Jack'D's, as a social media application, can help introverted gay men to find their world. Based on the research findings, it can be seen that Jack'D has a feature that allows a user to easily get a partner through the GPS that is integrated into the social media. It was also stated that an innovation can be accepted, according to Hanafi (1981), if it brings benefits to the individual.

Social media has provided a comfortable space for gay men, especially if the social media platform is specifically designed to meet the needs of gay men. The convenience that it has provided has made social media a popular medium for communicating with friends who share similarities. The Jack'D application, a social media network equipped with a gay radar through GPS, can make it easier for gay men to make close friends.

Social media is a fairly advanced tool used when creating good relationships with new people. The easy accessibility of internet networks has proven that social media is the right platform to make new friends. Social media specifically designed for gay men is one of them.

\section{As a media to make new friends with a similar orientation}

The presence of social media has become a special variable for gay men. Based on the research findings, it is known that the existence of Jack' $D$ as form of social media enable gay men to easily make new friends. As mentioned by Nwazor and Godwin-Maduike (2015), social media can be used to connect with other people, whether for business or commercial purposes, or to allow them to make new friends. According to Baruah (2012), a social media presence such as Jack'D for gay men bridges the gap between new people, and it offers a platform for online users to find other 
people who share common interests and allows them to build virtual communities based on mutual interests. Furthermore, it is also supported by Hertlein \& Ancheta (2014) who explained that social media technology is used to some extent to develop relationships. Many participants noted the fact that technology helped them to "meet new people", allowing "people with the same beliefs, hobbies, and habits to find each other more easily". In addition, Cassidy and Wang (2018), in their research, suggested that social media used for communication between gay men makes it easy for them to find the closest group members to meet, to arrange offline meetings, or to discuss tactics to find friends and/or boyfriends with a wider reach. These conveniences cause many gay communities to use social media to make new friends who have the same sexual orientation.

Based on the explanation above, the role of Jack' $\mathrm{D}$ as a social media platform in general is as one of the media platforms used to make new friends through online networks. The features provided by Jack'D allow gay men to make new friends easily; therefore the network of gay men becomes wider due to the presence of social media. Based on the research previously conducted, it can also be concluded that Jack'D's holds a special role for gay men to allow them to get friends with similar conditions. It has been mentioned by Baruah (2012) that social media has offered an online platform to find other people who share similar interests. Thus, Jack'D has an important role for gay men to use to discover new friends who have similarities as there are no differences that arise within their social interactions.

Friendship that is built from social media is not limited to one or two people, but multiples. This interaction with numerous gay men can grow bigger into an online community based on social media which facilitates their interaction. This happens because they share the similar status of being a minority in society. The formation of these online communities has its own advantages in building their own social network.

According to the research findings, many gay men are secretly hide their identity because of the fear of intimidation from their family or closest friends who do not accept their sexual orientation and preferences. According to Australia's Department of Health and Aging (2012), this has led gay communities to have strong connections within their own communities. Denial by their surroundings and the closest people to them triggers them to build intimate relations with non-biological family members who they consider to be their family of choice. This community may be more important to gay men compared to their own biological families.

Due to this particular situation, the role of social media specifically designed for gay men like Jack'D is an option for homosexuals to find a community that can accept them as a normal individual and as a valid part of the community. The important role of social media as a tool to make friends and build a community is a part of gay activities on social media.

\section{As a media of communication among gay men}

Friendships with fellow men on social media commence through communications with others. Interactions with friends on social media occur because, according to Slamet (2010), individuals face social situations with other individuals. It has been proven that in social situations, each individual communicates with other individuals. The results of these communications may result in many gay men being comfortable with the existence of social media such as Jack'D.

Social media specifically designed for gay men such as Jack'D are a platform for communication that relies on the media as a tool to connect people. Social media for gay men plays a role in media communication which, according to Slamet (2010), is a communication that occurs between communicators and communicants who use tools / media. The media is considered to be a link to convey messages between gay men.

So far, gay men have encountered difficulty in communicating openly with other gay men in the real world. This is based on the research findings which show that many gay men hide their identity 
to their straight friends and/or family. Difficulties in communicating openly with each other can be overcome by the presence of social media. This refers to a statement from Hertlein \& Ancheta (2014), stating that the presence of communication technology (social media) can reduce anxiety in difficult conversations. Moreover, the presence of social media helps people to gain self-confidence; those who are getting helped are those who are reluctant to discuss intimate sexual topics or topics. The same idea was expressed by Syahputra \& Yuliana (2016), who mentioned that gay men within the LGBT community in Indonesia, including gay men who are trying to adapt to the existing conditions, are trying to find ways to meet their needs. The development of information technology has helped to change methods of communication of gay communities, allowing them to interact with those who share the same sexual orientation.

Based on the previous discussion, the presence of social media platforms such as Jack' $\mathrm{D}$ holds the role as a medium of communication and a platform that connects gay men. The presence of social media as a communication medium also serves as a tool to overcome the anxiety arising from identity issues. Because Jack'D is designed specifically for gay men, they can communicate freely with anyone that they want to without fear of intimidation.

Based on the research findings, it was found that social media specifically designed for gay men like Jack'D was created according to the need to find and communicate with fellow gay men. Jack' $D$ is an effective communication tool. This is also supported by the statement from Panahi, Watson \& Partridge (2012) stating that social media has provided an effective channel for social interaction and real time conversations between users in the form of chat. The existence of social media as a communication media specifically designed to bring together gay men in a chat room will lead to a more effective communication overall. The term effective communication, according to Mulyana (2012), can be explained by the more similar the socio-cultural background is between people, the more effective their communication is. For example, sharing a similar identity of being gay and other mutual interests can lead to a more effective communication channel as they have something in common.

The emergence of social media specifically designed for gay men has played a role as a medium for gay men to be able to communicate easily without fear of intimidation or negative prejudice from their interlocutors. The existence of this type of social media has increasingly made gay men more confident in showing their identity and coming out of the closet.

\section{As a medium to fulfill the need to be accepted}

The existence of social media such as Jack'D is specifically designed for gay men as one of the communication media outlets has brought together gay communities. Based on the research findings, it was found that gay men chose this social media network because they want to make likeminded friends to be able to communicate easily with without any threat from homophobic people. Furthermore, the presence of social media enables gay men to be more open regarding their identity and therefore increases the chance of them being accepted by others.

As can be seen from the conditions described previously, there is a reason why gay men need social media; it is as means to be acknowledged as a normal human despite having a different sexual orientation to the social norm. Therefore, gay men communicate using social media such as Jack'D, which, according to Slamet (2010), is because humans are not only living in the world, but they are also have to live against the world where they face opposition. In living against the world, human beings understand the ego of what they are facing. Thus, humans are subjects who are aware of themselves and who are aware of the existence of other subjects. This awareness provides the opportunity for human beings to communicate with others so then their existence as a human being is acknowledged. According to Mulyana (2012), communication is important and therefore social communication must be respected and accepted for survivability and happiness. Social media, as a media used for communication, helps to increase social acceptance from other people. This is also in accordance with the research conducted by Chong et al (2015) about gay men in Hong Kong, which found that the presence of social media serves as a valuable social capital to encourage resilience and 
support for one another, to be a tool of acceptance without discrimination and negative social stigma, and to catalyzes the development of a balanced community. Therefore, it is positive that social media is one of the media outlets or tools used to fulfill the need to be appreciated and accepted. The presence of social media specifically designed for gay men, such as Jack'D, influences the sustainability of homosexuals in maintaining their identity. Social media is used as a way to receive acknowledgement from fellow gay men that they meet through chatting in the social media chat room.

\section{Conclusion}

Social media can be used by gay men to find partners, as social media provide profile photo features that can be used by its users to look for new partners. Moreover, the emergence of a gay radar through GPS is a new innovation in social media applications specifically designed for gay men (Jack'D), which makes it easier for gay men to find new friends which are located in close proximity to them. The advantages of social media specifically designed for gay men make them a top choice as a media to interact and communicate with fellow gay men. Another role of this type of social media is as a platform of communication. The next role that it has is as a tool to fulfill the need to be accepted (or the need to be acknowledged) as a human being. The presence of this form of social media is utilized by gay men to interact with one another so then they receive acknowledgement as a human being with self-identity.

\section{References}

Achew MO \& Larson AG (2015) Use of social media and its impact on academic performance of tertiary institution students: A study of students of Koforidua Polytechnic, Ghana. Journal of Education and Practice 6 (6):94-101.

Baruah TD (2012) Effectiveness of social media as a tool of communication and its potential for technology enabled connections: A micro-level study. International Journal of Scientific and Research Publications 2 (5):1-10.

Cassidy E \& Wang WY (2018) Gay men's digital cultures beyond Gaydar and Grindr: LINE use in the gay Chinese diaspora of Australia. Information, Communication \& Society 21 (6):851865. DOI:10.1080/1369118x.2018.1437201.

Chong ES, Zhang Y, Mak WW, \& Pang IH (2015) Social media as social capital of LGBT individuals in Hong Kong: Its relations with group membership, stigma, and mental well-being. American Journal of Community Psychology 55 (1):228-238. DOI 10.1007/s10464-014-9699-2.

Department of Health and Ageing (2012) National Lesbian, Gay, Bisexual, Transgender and Intersex (LGBTI) Ageing and Aged Care Strategy. Canberra: Commonwealth of Australia.

Fassin E \& Salcedo M (2015) Becoming gay? immigration policies and the truth of sexual identity. Archives of Sexual Behavior 44 (5):1117-1125. DOI 10.1007/s10508-015-0551-z.

Hana U (2013) Competitive advantage achievement through innovation and knowledge. Journal of Competitiveness 5 (1), 82-96. DOI: 10.7441/joc.2013.01.06.

Hanafi A (1981) Memasyaratkan Ide-ide Baru. Surabaya: Usaha Nasional.

Harahap RDKA (2016) LGBT di Indonesia: Perspektif hukum Islam, HAM, psikologi dan pendekatan mașlaḥah. Al-Ahkam 26 (2):223-248.

Hertlein KM \& Ancheta K (2014) Advantages and disadvantages of technology in relationships: Findings from an open-ended survey. The Qualitative Report 19 (22):1-11.

Mingle J, Adams M, \& Adjei EA (2016) A comparative analysis of social media usage and academic performance in public and private senior high schools. Journal of Education and Practice 7 (7):13-22.

Mulyana D (2012) Ilmu Komunikasi: Suatu Pengantar. Bandung: Remaja Rosdakarya. 
Nwazor J \& Godwin-Maduike CC (2015) Social media and academic performance of business education students in South-East Nigeria. Journal of Education and Practice 6 (25):127-134.

Okereke CE \& Oghenetega LU (2014) The impact of social media on the academic performance of university students in Nigeria. Journal of Education and Practice 5 (33):21-24.

Panahi S,Watson J, \& Partridge H (2012) Social media and tacit knowledge sharing: developing a conceptual model. World Academy of Science, Engineering and Technology 6 (4):10951102.

Puspita Y (2015) Pemanfaatan new media dalam memudahkan komunikasi dan transaksi pelacur gay. Jurnal Penelitian Komunikasi, Informatika dan Media Massa (Pekommas) 18 (3):203-212.

Santrock JW (2013) Adolescence ( 15 th. ed). New York: McGraw-Hill Education.

Slamet S (2010) Teori-teori Psikologi Sosial. Bandung: Refika Aditama.

Sujana IN, Setyawati KA, \& Ujanti NMP (2018) The existence of the lesbian, gay, bisexual and transgender (LGBT) community in the perspective of a state based on pancasila. Mimbar Hukum 30 (1):127-139. DOI: 10.22146/jmh.28655.

Syahputra RH \& Yuliana GD (2016) Komunikasi homoseksual berbasis teknologi. Jurnal Komunikasi Indonesia 5 (2):137-153.

Wijoyo H (2016) Hegemoni dalam emansipatory: Studi kasus advokasi legalisasi lesbian, gay, biseksual, dan transgender di Indonesia. Indonesian Perspective 1 (2):31-47. 